\title{
2005 DOE Hydrogen Program Review Hydrogen Codes and Standards
}

\author{
Jim Ohi \\ National Renewable Energy Laboratory \\ May 26, 2005
}

Project ID\# SA2

This presentation does not contain any proprietary or confidential information 


\section{Overview}

\section{Timeline}

- Project start date: 10-1-04

- Project end date: 9-30-05

- Percent complete: 50

\section{Budget}

- Total project funding

- DOE share: \$1.6M

- Contractor share: $\$ 10 \mathrm{~K}$

- Funding received in FY04: \$2.0M

- Funding for FY05: \$1.6M

\section{Barriers}

- Codes and Standards Barriers addressed

- Consensus national agenda on codes and standards (J,A,B,D,L)

- Limited DOE role in the development of ISO standards and inadequate representation by government and industry at international forums $(F, G, H, I, K)$

- Current large footprint requirement for hydrogen fueling stations $(\mathrm{P}, \mathrm{N}, \mathrm{M})$

\section{Partners}

- National Hydrogen and Fuel Cells Codes and Standards Coordinating Committee

- FreedomCAR-President's $\mathrm{H}_{2}$ Fuel Initiative C\&S Tech Team

- North American Hydrogen Fuel Quality Team 


\section{Objectives}

- Develop and implement consensus national agenda on domestic and international codes and standards for hydrogen systems in commercial, residential, and transportation applications

- Enhance DOE's role in development of ISO and other international standards and strengthen representation by government and industry at international forums

- Facilitate harmonization of requirements for hydrogen applications based on consensus R\&D

- Integrate codes and standards activities from R\&D to precommercialization 


\section{Approach}

- Develop unified national agenda for codes and standards

- National templates adopted by consensus of SDO/MCDs

- accelerate development of priority standards

- designate and support lead SDO/MCDs

- facilitate access to standards/model codes through ANSI website

- Coordinate national/international codes and standards activities

- National $\mathrm{H}_{2} /$ Fuel Cells Codes and Standards Coordinating Committee

- Coordinate R\&D through Codes and Standards Tech Team R\&D Roadmap

- Hydrogen Behavior

- Vehicles

- Fuel Infrastructure

- Fuel-Vehicle Interface

- fuel quality specifications

- integrated safety engineering

- Harmonize technical standards and global technical regulations

- International template 


\section{Approach}

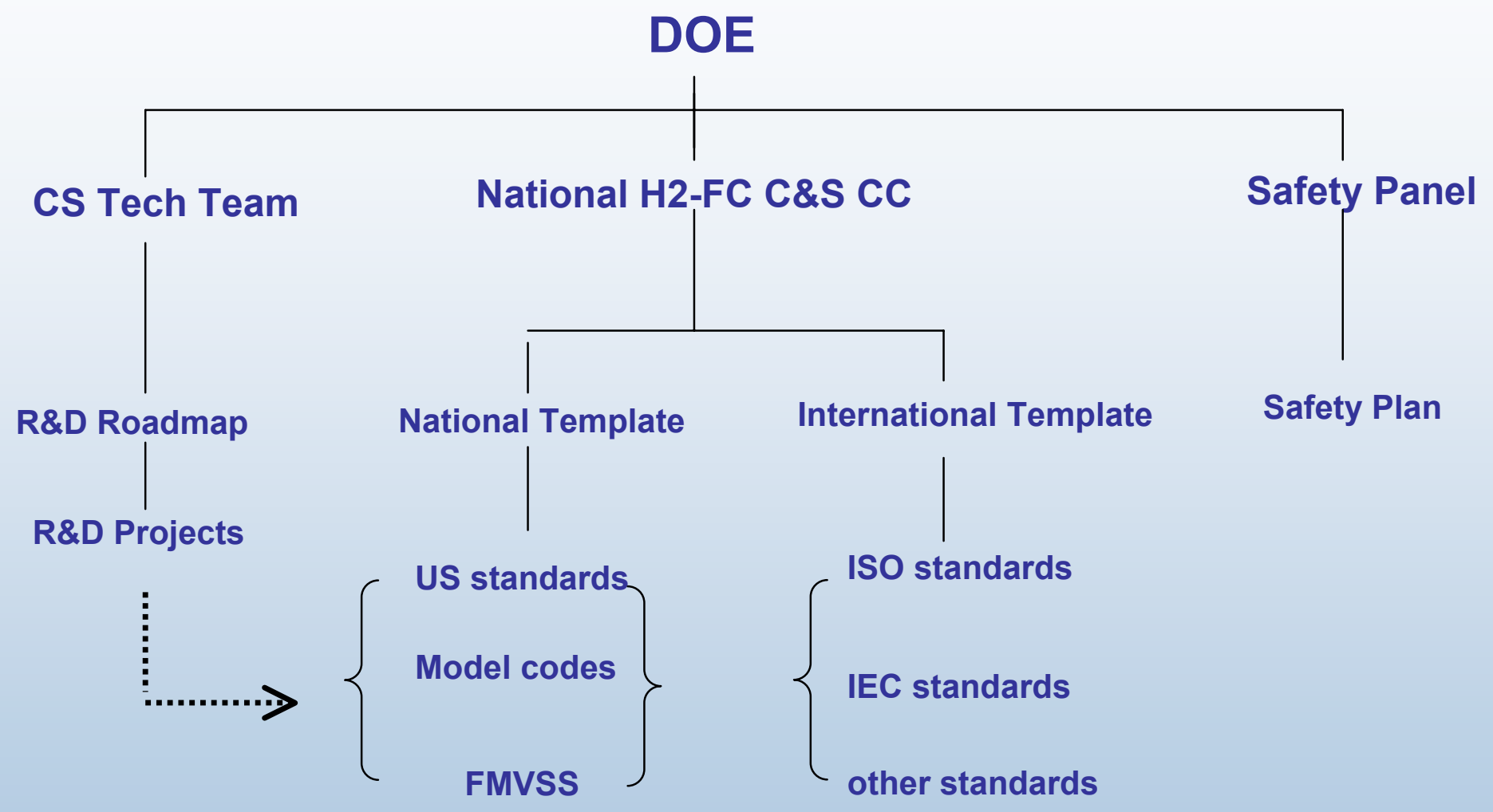

Global Technical Regulations 


\section{Approach}

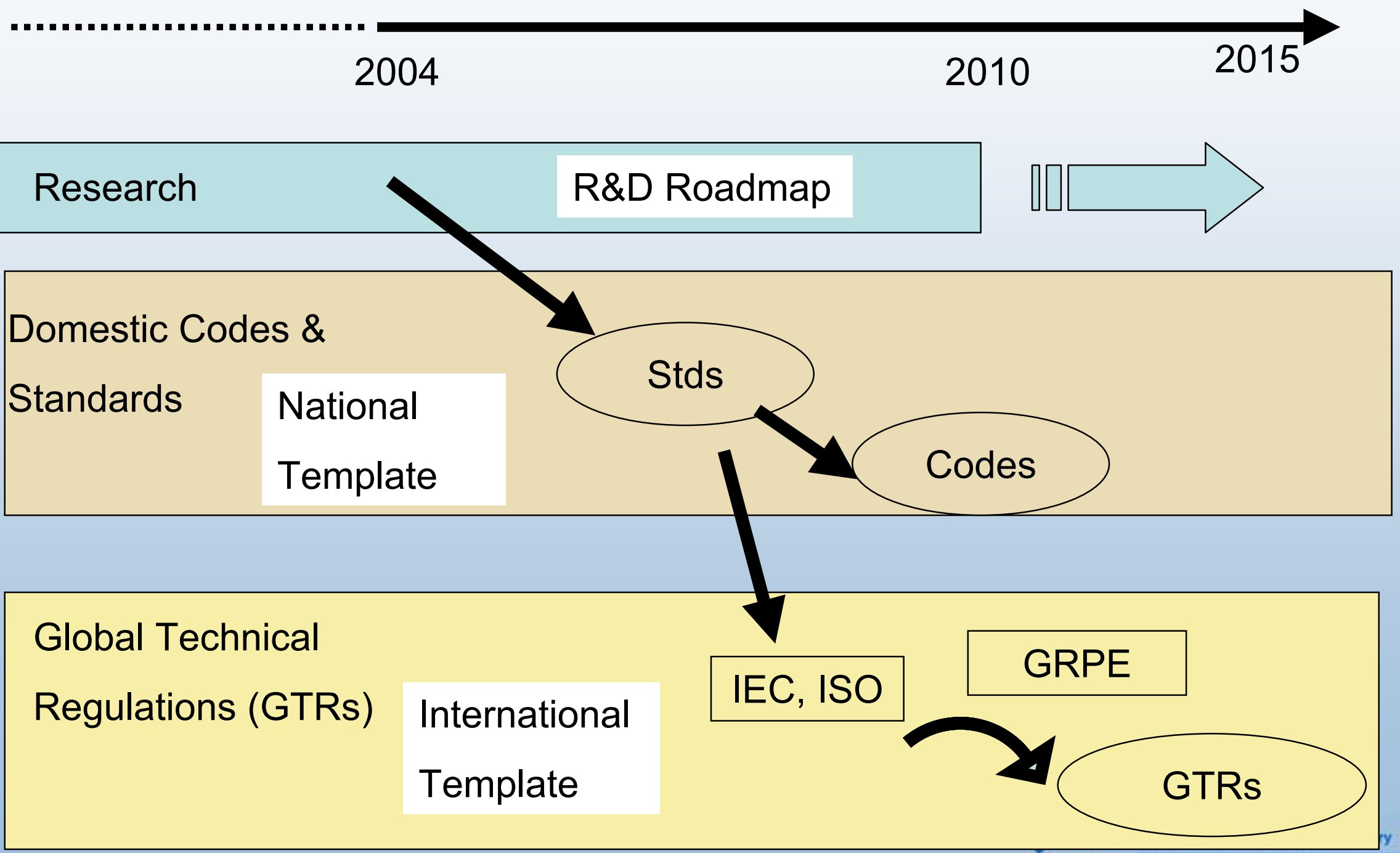




\section{Approach: Overall Timetable}

2004 2006 2008

Release Scenarios

$\mathrm{H}_{2}$ Behavior

FVC Formation

LFL
Materials Handbook

Whole System

Design

[R\&D Roadmap]

\section{Sensors}

\section{Setbacks \\ Bulk Storage \\ Containers \\ Dispensing \\ Systems \\ Pipelines \\ Fuel Specs}

Crashworthiness

Modeling, Testing

FMVSS

Draft GTR

Vehicle Systems

R\&D

Codes and Standards

Regulations

Commercialization Decision 


\section{Technical Accomplishments/Progress}

- Unified national agenda for codes and standards

- consolidated national coordination groups and activities

- DOE, USFCC, NHA created National H2-FC C\&S Coordinating Committee

- establish national focal point and consensus on key C\&S issues, needs

- ANSI hydrogen portal (www.hcsp.ansi.org)

- incorporated C\&S matrix and website (www.fuelcellstandards.org)

- agreement with key SDO to post and browse $\mathrm{H}_{2} / \mathrm{FC}$ standards and model codes

- work with all key SDO/MCO to develop essential standards and model codes

- Coordinate R\&D to develop defensible standards for hydrogen systems

- Codes and Standards Tech Team and R\&D Roadmap implementation

- initiate whole-system engineering research approach for hydrogen safety

- coordinate long-term R\&D/test plan for hydrogen fuel quality

- Harmonize technical standards and global technical regulations

- member US Technical Advisory Group, ISO/TC197, Hydrogen Technologies

- member of ISO/TC197 WG 12 to prepare hydrogen fuel quality specification

- work with CGA and CSA to coordinate ISO/TC197 and IEC/TC105 


\section{Technical Accomplishments/Progress}

- Support and facilitate development of standards and model codes

- Draft standards for fueling systems, containers (on-board), sensors, fuel cells for hand-held devices and telecommunications under review

- Draft standards for piping, bulk storage, composite containers, transportable containers under way

- Fuel cell electric vehicle standards published, under review, or being developed

- Draft ISO Technical Specification for hydrogen fuel quality under review

- Model codes will provide for additional hydrogen applications

- 2006 ed., International Code Council model codes

- NFPA 52 and 55 under revision 


\section{Technical Accomplishments: Fuel Quality}

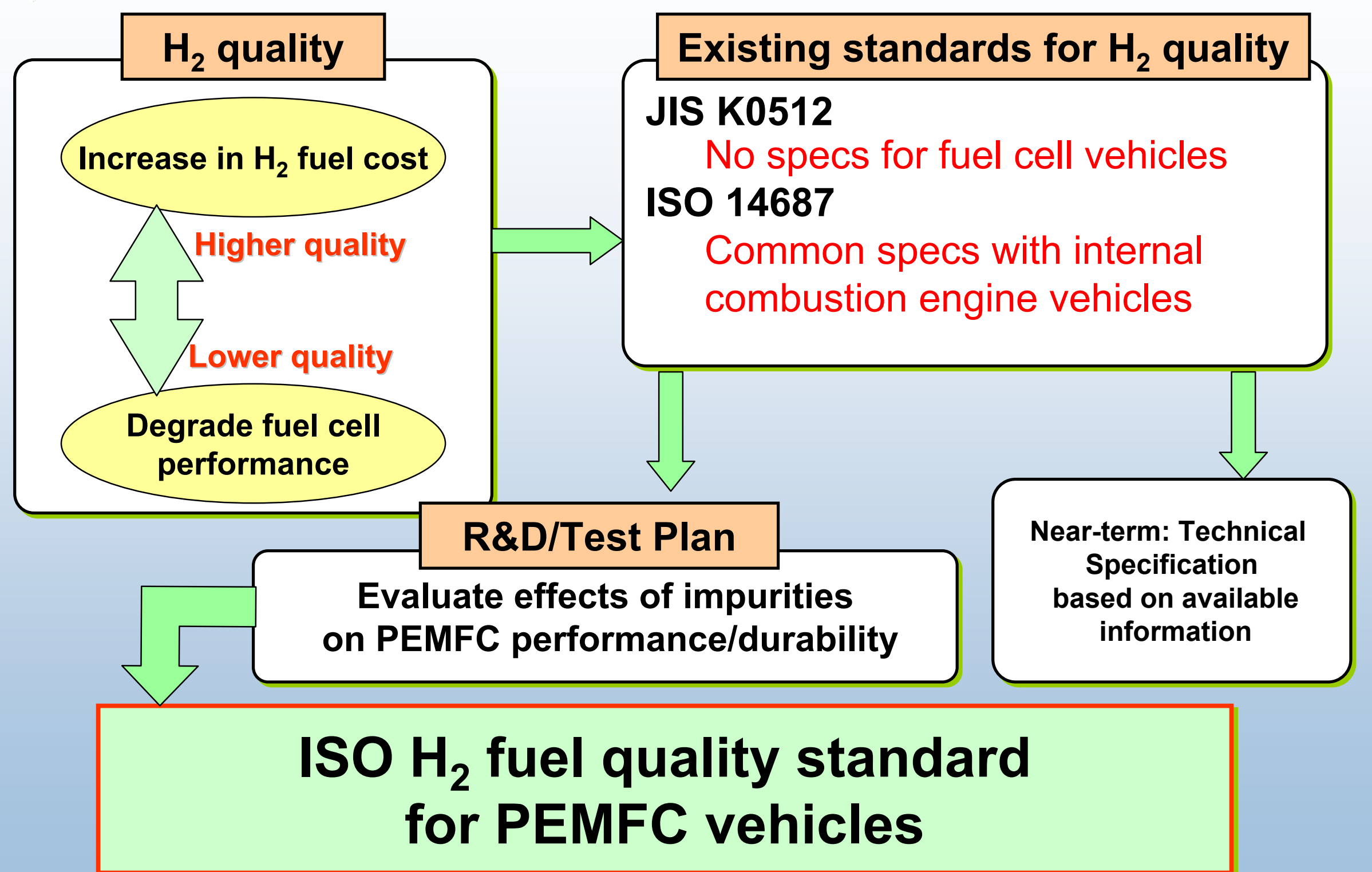




\section{Technical Accomplishments:Development of International $\mathrm{H}_{2}$ Fuel Quality Standard (PEMFC Road Vehicles-Anode)}

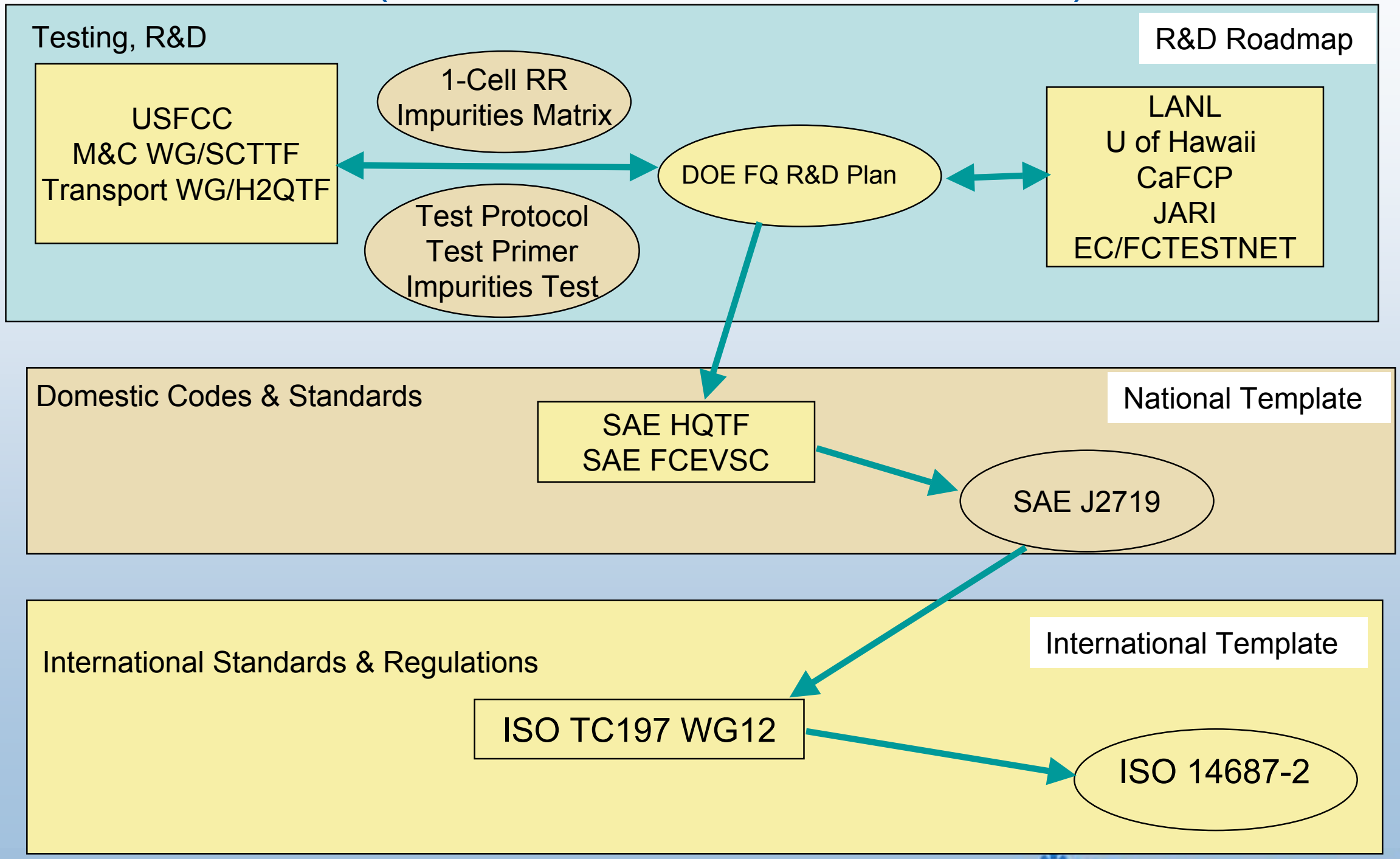




\section{Technical Accomplishments: International Template for Hydrogen Standards and Regulations}

\section{Standards/Codes}

\section{Key International Organizations:} IEC, ISO

Key Domestic Organizations: ANSI, ASME, CGA, CSA, SAE, UL ICC, NFPA

DOE, DOT, EPA, NASA, NIST

NHA, USFCC, CaFCP

Key Foreign Organizations Japan: METI, NEDO, JARI EU: FCHP

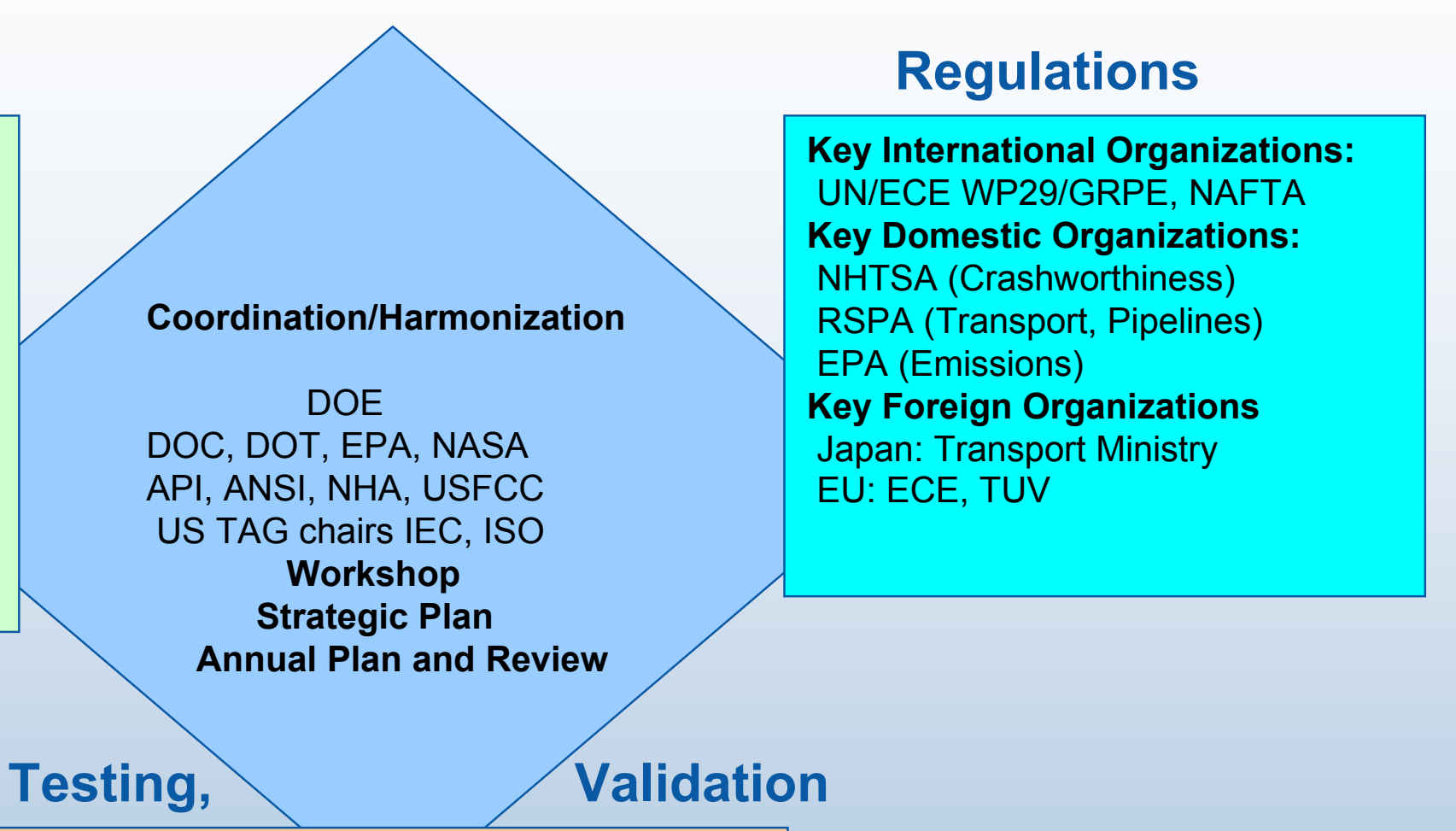

Key International Organizations IPHE

Key Domestic Organizations:

ASTM,CaFCP, DOE, NHA, NASA, NIST

USFCC, national labs, universities

Key Foreign Organizations

Japan: Millennium Project, FCCJ, JARI

EU: FCTESTNET, FCTESTQA, HySafe

Canada: CFCTA
Key International Organizations:

UN/ECE WP29/GRPE, NAFTA

Key Domestic Organizations:

NHTSA (Crashworthiness)

RSPA (Transport, Pipelines)

EPA (Emissions)

Key Foreign Organizations

apan: Transport Ministry

EU: ECE, TUV 


\section{Technical Accomplishments: Harmonization of International Standards and Regulations}
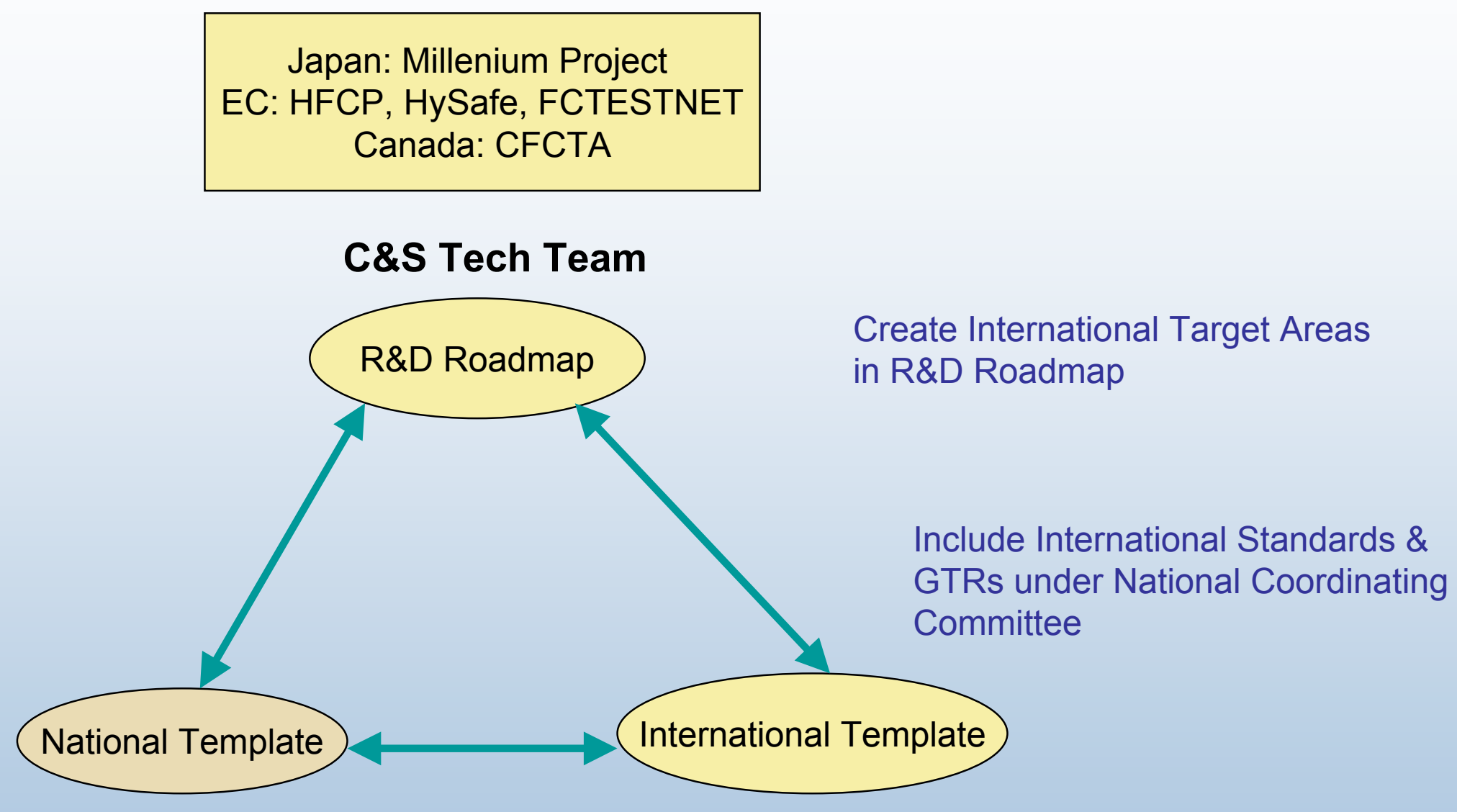

National H2-FC C\&S CC

US TAGs ISO TC197, TC22/SC21

IEC TC105

WP29/GRPE--EPA/NHTSA 


\section{Responses to Previous Year Reviewers' Comments}

- Clear definition between portions of budget directed toward code setting bodies, ...., etc., and that part ... used specifically for R\&D

- R\&D part (fuel quality, testing/validation, integrated engineering) are separate subtasks in FY05

- National/international templates, subcontracts to SDOs are separate subtasks in FY05

- Gather international input if available

- developing international template for standards and regulations

- developing international collaboration on R\&D for hydrogen safety, codes and standards

- member of US delegation to ISO TC197 plenary

- member of US TAG to ISO TC197

- working with JARI, FCTESTNET, HySafe, HyApproval, etc. 


\section{Future Work: Codes and Standards Development}

- Expand coordination role for national template

- re-evaluate C\&S development, synchronize with R\&D

- transition to performance-based standards

- Develop and implement international template for hydrogen-fueled vehicles based on GTR process

- on-board storage components and subsystems

- whole-vehicle safety

- energy, environmental considerations

- Develop sustained industry participation in ISO, IEC, and GTR process to implement international template

- bring international standards and regulations coordination under purview of National H2-FC C\&S Coordinating Committee

- coordinate linkages to EC and Japan 


\section{Future Work: R\&D for Safety, Codes \& Standards}

- Conduct scenario analysis/risk assessment for R\&D priorities

- Coordinate R\&D for Vehicle-Fuel Interface Focus Area

- integrated engineering and design

- whole-system safety requirements and evaluation

- link R\&D in all four focus areas

- system design approaches to meet technical requirements

- innovative approaches to inherently safe, energy efficient design

- case studies

- link to DOE fleet vehicle validation sub-program, other demo-validation projects

- fuel quality

- develop and coordinate comprehensive testing project

- refueling station

- coordinate feedback strategies, dispenser testing

- develop, test siting template in key states, e.g., CA Hydrogen Highway

- Conduct and coordinate R\&D for Detection and Mitigation

- comprehensive testing and verification project

- detection technology development, testing, and verification 


\section{Future Work: Address Hydrogen Fuel Specifications for Total Energy Cycle}

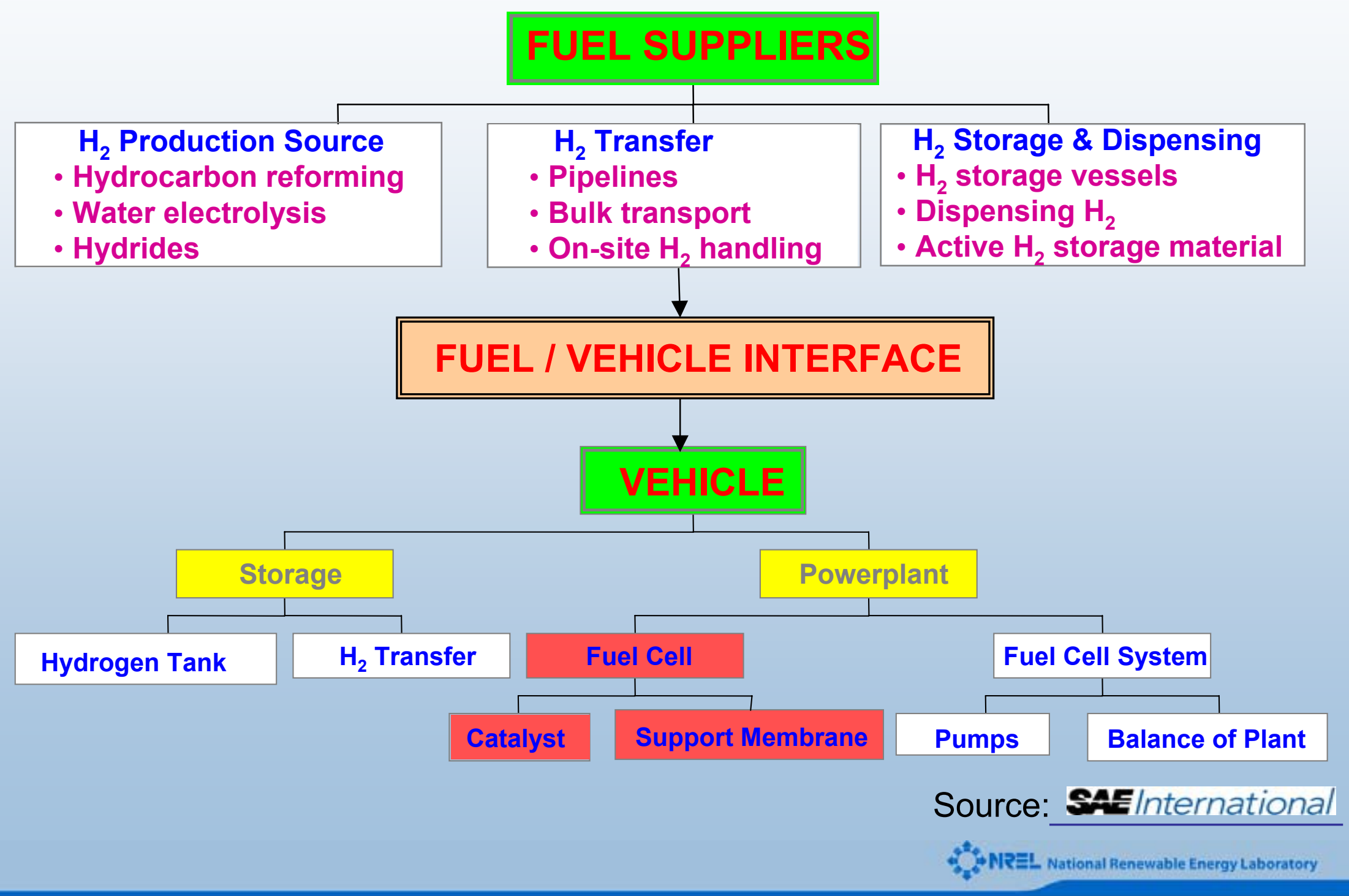


Future Work: Time Phasing of Standards and Rulemaking with Technology Development

\section{Concept Cars} Is it real?
Demo Cars

Can we do it?

100 's

\section{Pre-Commercial}

Is it viable?
Global

Volumes
Production

1,000 's

Guidelines \& Best Practices

Rapid technology advances

$\&$ demo experiences

Industry Standards

\section{Validation \&} experience

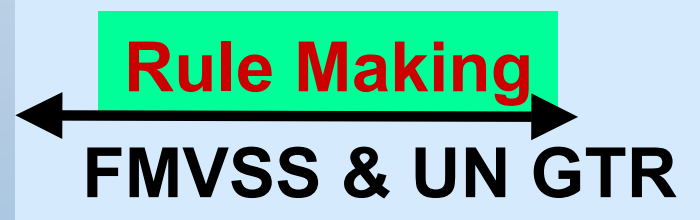

$\stackrel{\text { Regulations }}{\longrightarrow}$

Commercial feasibility 


\section{Future Work: Timetable for Fuel Quality Standard}

2004 2007 2010

FCVs introduction stages

Initial introduction (Fleet, Demo)

Mass production

Corresponding fuel requirements

End of 2005

ISO14687

Cor

Exclude "PEMFC" from "ISO14687-1"

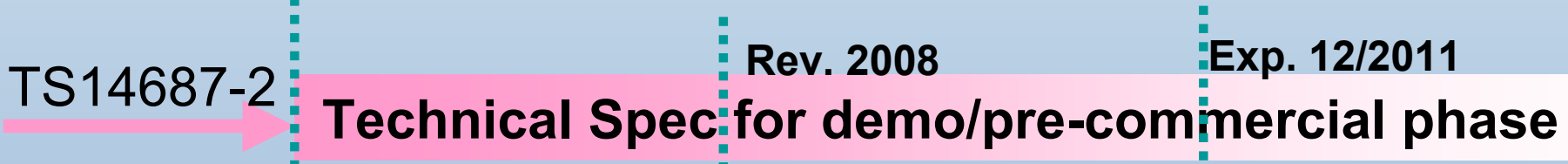

Long term: ISO 14687-2

(includes global R\&D/testing)

Standard for mass production 


\section{Future Work: Fuel Quality}

- Prepare Technical Corrigendum for ISO 14687

- Remove references to fuel cells

- Prepare Technical Specification for hydrogen fuel quality for PEM fuel cells for road vehicles

- Prepare consensus data table at next meeting, January 2005

- Refine single-cell baseline testing at University of Hawaii

- Ballard, GM, UTC donating test hardware, expertise

- Develop joint R\&D Plan for fuel quality

- Part of overall Japan-US-EU collaboration on RD\&D for hydrogen safety, codes and standards

- METI/NEDO-DOE workshop to initiate joint RD\&D Plan

- invite EU participation to draft RD\&D Plan

- annual meeting on R\&D(Japan, US, EU)

- exchange information and data

- coordinate strategy for international standards, GTRs 


\section{Future Work: Fuel Quality R\&D}

- Develop R\&D plan and testing program as foundation for international hydrogen fuel quality specifications

- Delineate key tasks, timetables, budgets

- Build on JARI, ASTM, USFCC, SAE, CAFCP, U of Hawaii, FCTESTNET work

- Incorporate into C\&STT R\&D Roadmap

- Develop collaborative international R\&D Plan

- Create and link expert teams in NA, Asia, EU

- Initiate R\&D and Testing

- Correlate activities to eliminate duplication of effort

- Provide strong NA technical support in meeting objectives

- Review Technical Specification

- Develop new ISO standard based on R\&D and test data

- Joint NA-Asia-EU effort 


\section{Future Work: Overall FQ R\&D Plan Approach}

Single-Cell Test Protocol

Steady-state Testing

Single-constituent Testing

Short-term Testing
Multi-cell Testing

Dynamic Testing

Dual-constituent Testing

Long-term testing
Short-stack Testing Duty cycle Testing Multi-constituent Testing Accelerated Life Testing
Advanced Analytic Techniques New Material \& Compositions Life Cycle Testing Fuel Cell Modeling

Vehicle Demonstration Information

Vehicle Systems Modeling Analyses of $\mathrm{H}_{2}$ Fuel at Site
Failure Mechanisms Regeneration Conditions Accelerated Test Protocol Material/Fuel Cell Modeling
Basic Degradation Paths Contamination Resistance Accelerated Test Correlation Total System Modeling Advanced Hydrogen Storage
Material

Production/Delivery Paths Systems/Cost/Data Analysis
Updated $\mathrm{H}_{2}$ Fuel Quality $\mathrm{H}_{2}$ Delivery/Vehicle Demos Demo Operation/Cost Analysis Correlation 


\section{Future Work: Coordinated Approach for GTRs}

- Develop and implement international template for US

- achieve NA consensus on GTR(s) for hydrogen fuel cell vehicle systems

- harmonize development of domestic standards and GTRs

- overall strategy, objectives, priorities, timing

- develop and support expert roster and assignment system

- support and coordinate key ISO/IEC TAGs and WG/SC

- Manage international template through National H2FC C\&S CC

- annual objectives, review strategy and priorities

- facilitate coordination through ISO TC197 US TAG website

- coordinate with C\&S Tech Team

- Facilitate collaborative R\&D effort with Japan and EU

- consensus testing/data to establish foundation for technical requirements

- start with hydrogen behavior, fuel quality specifications

- harmonized test and validation protocols 


\section{Partners for Hydrogen Fuel Quality}

- DOE Hydrogen, Fuel Cells and Infrastructure Technologies

- Pat Davis, Antonio Ruiz

- SAE International Hydrogen Quality Task Force

- USFCC Joint Hydrogen Quality Task Force

- $\quad$ ISO TC197 Working Group 12

- Professor Yasuo Takagi, Musashi Institute of Technology, Convener

- Dr. Hidenori Tomioka, JARI, Secretary

- $\quad$ ISO TC197 US TAG and WG12

- "North American $\mathrm{H}_{2}$ FQ Team"

- Bill Collins, UTC Fuel Cells (USFCC, SAE)

- Tony Estrada, PG\&E (ASTM)

- Karen Hall, NHA (ISO TC197)

- Rick Rocheleau, University of Hawaii

- Jesse Schneider, Daimler-Chrysler (CaFCP)

- Ron Sims, consultant to NREL (SAE)

- Mike Steele, Stella Papasavva, GM (SAE)

- Andrei Tchouvelev, Hydrogenics

- Gerald Voecks, consultant to NREL

- Silvia Wessel, Ballard Power Systems

- Doug Wheeler, consultant to NREL

- Robert Wichert, USFCC 


\section{Supplemental Slides}

The following six slides are for the purposes of the reviewers only. 


\section{Publications and Presentations}

Patents: Two under preparation for hydrogen safety sensor

Papers:

- Hydrogen Codes and Standards: An Overview of U.S. DOE Efforts (with DOE), WHEC 15, Yokohama, Japan

Presentations:

- ANSI Hydrogen Codes and Standards Portal, New York State Building Officials Conference, Albany, NY

- FCTESTNET conference and international workshop on codes and standards, Ulm, Germany

- NHA Annual Conference, Los Angeles, CA

- NHA workshops, Fuel Cell Seminar, San Antonio and SCAQMD, Diamond Bar, CA

- World Hydrogen Energy Conference 15, Yokohama, Japan

- ISO TC 197 Working Group 12, Newcastle, UK

- DOE Hydrogen Safety Panel, Washington, DC 


\section{Hydrogen Safety}

To date, no hydrogen hazards have been associated with this project as no laboratory or field work has been conducted. Fuel quality testing initiated at the University of Hawaii is funded under a different program. 


\section{Hydrogen Safety}

When fuel quality or other testing is initiated under this project, our approach to deal with hazards is to:

- follow all provisions of the Guidance for Safety Aspects of Proposed Hydrogen Projects issued by the DOE Hydrogen Safety Panel

- follow all relevant provisions contained in test protocols

- follow all standard operating procedures established by the institution conducting the tests 


\section{International Landscape of Vehicle Legal Requirements and Standards}

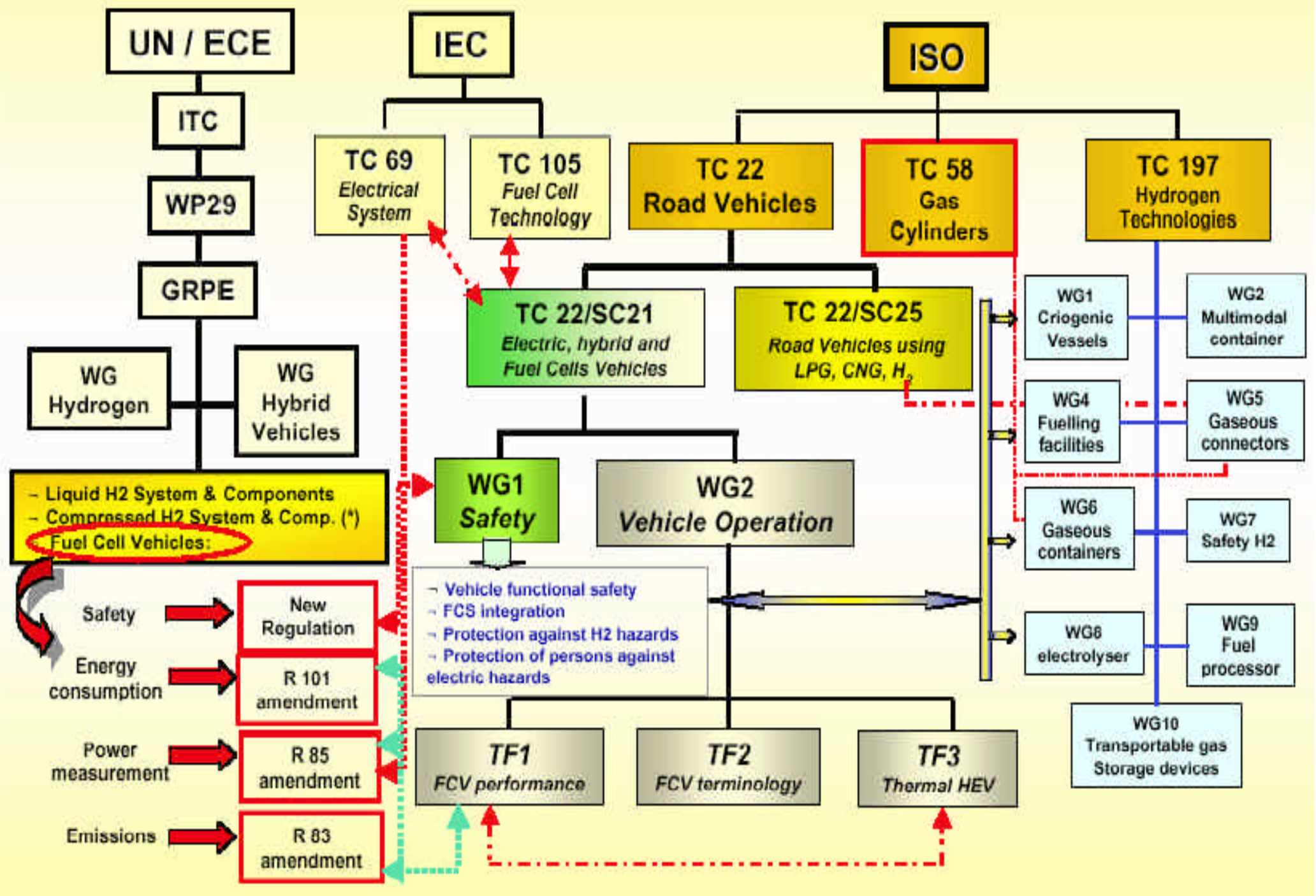




\section{Globally Harmonized Vehicle Approval - Possible Pathwe}

Target date for GTR: 2010

Target date for ECE: 2006

GTR (Global Technical Regulation) 1998 Agreement

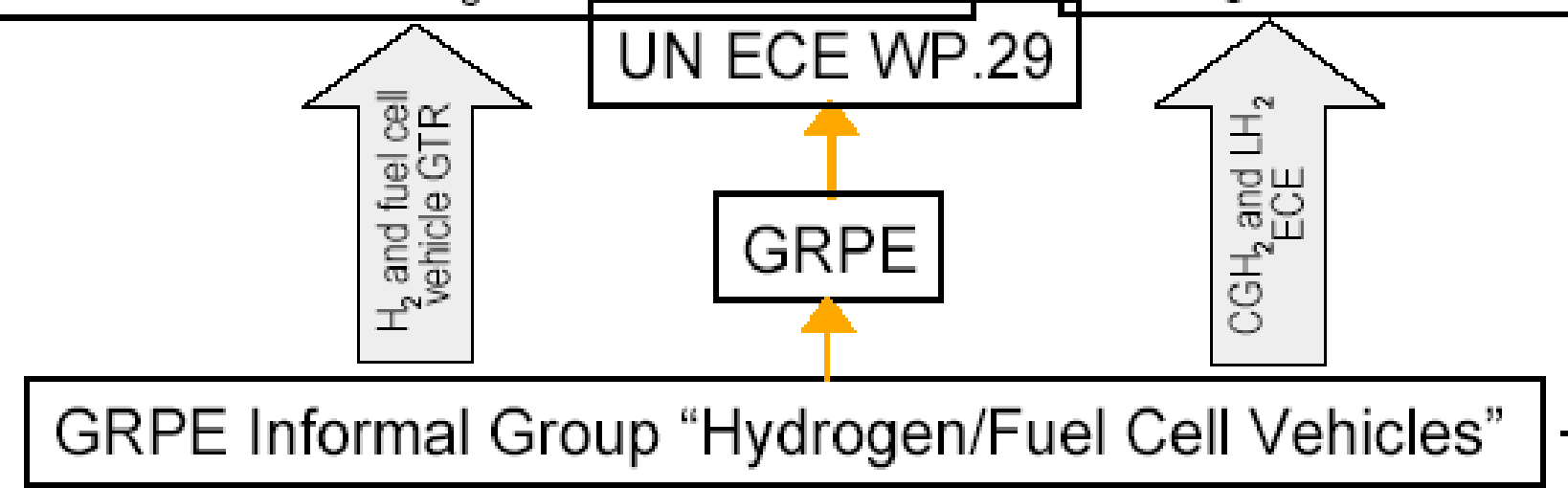

UN ECE WP.29

ECE

Regulations

1958 Agreement

GRPE Informal Group "Hydrogen/Fuel Cell Vehicles"

$\mathrm{H}_{2}$ Industry

mobile

Voice

and stationary

\section{EIHP2 Partnership}

ElHP was a partnership between the European Hydrogen Industry and the European Commission. This consortium was created to provide inputs for regulatory activities on a European and global level to facilitate harmonized Procedures for the approval of hydrogen fuelled road vehicles.

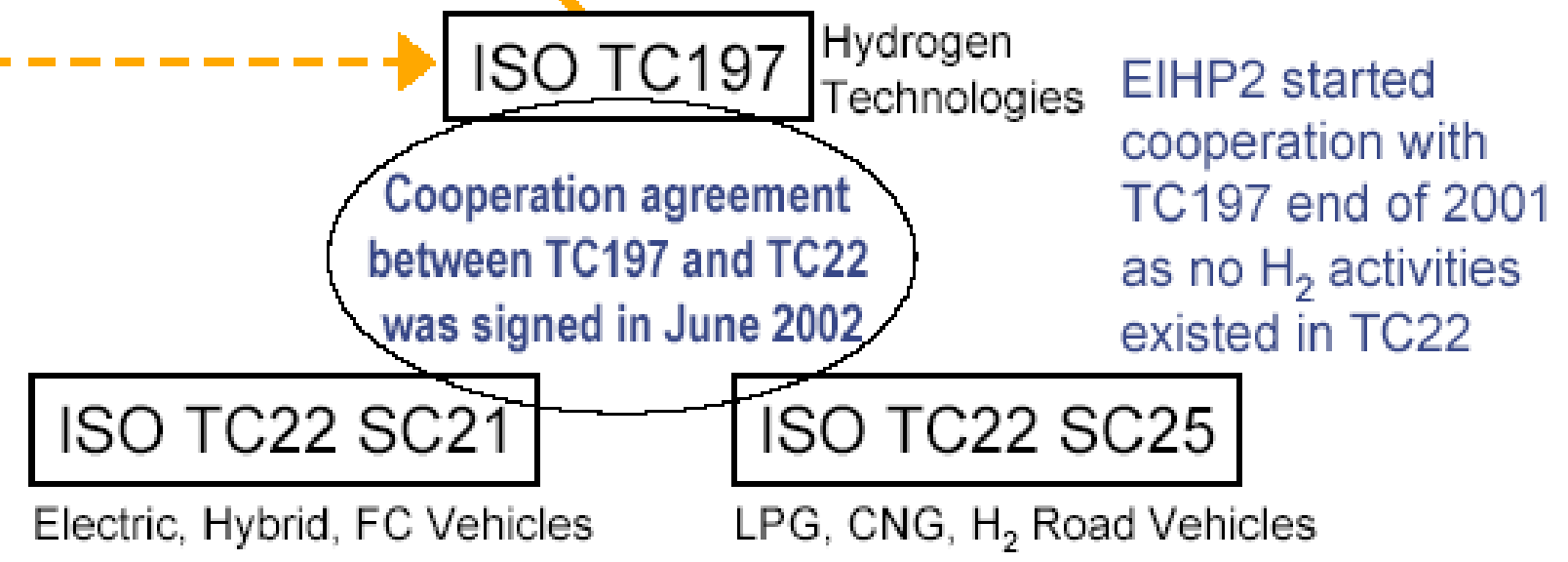

Authorities, testing agencies, component suppliers, vehicle manufacturers 


\section{Future Work: Test Plan-Part 1}

Specifically address vehicular PEM fuel cell performance issues affected by $\mathrm{H}_{2}$ fuel contaminants

- Identify relationships between contaminant type/level and fuel cell material properties, considering:

- anode catalyst

- membrane material

- MEA assembly

- contaminant species

- fuel cell operating conditions

- Provide basis from which to better define $\mathrm{H}_{2}$ fuel quality

- use in conjunction with vehicle system requirements (storage, BOP, etc.)

- serve as guide for $\mathrm{H}_{2}$ fuel providers/suppliers

- Generate database from which alternative resolutions may result

- alternate materials (MEA) that are contaminant 'immune'

- regenerative procedures (operational functions) for performance recovery

- Provide basis for international collaboration

- address issues common to all PEM fuel cell vehicles

- data to help guide DOE-funded activities 